\section{References}

1 Walsh JJ, Bonnar JN, Wright FW. A study of pulmonary embolism and deep leg vein thrombosis after major gynaecological surgery using labelled fibrinogen, phlebography and lung scanning. Fournal of Obstetrics and Gynaecology of the British Commonwealth 1974 ;81 :311-6.

2 Gallus AS, Hirsh J, Tuttle RJ, et al. Small subcutaneous doses of heparin in prevention of venous thrombosis. $N$ Engl f Med 1973;288:545-51.

${ }^{3}$ International Multicentre Trial. Prevention of fatal post-operative pulmonary embolism by low doses of heparin. Lancet 1975 ;ii:45-51.

4 Lahnborg G, Bergstrom K, Friman L, Lagergren H. Effect of low dose heparin on incidence of post-operative pulmonary embolism detected by photoscanning. Lancet $1974 ; \mathrm{i}: 329-31$.

5 Belch JJF, Lowe GDO, Pollock JG, Forbes CD, Prentice CRH. Subcutaneous heparin in the prevention of venous thrombosis after elective aortic bifurcation graft surgery. Thromb Haemostas 1979;42:303.

${ }^{6}$ Clayton JK, Anderson JA, McNicol GP. Preoperative prediction of postoperative deep vein thrombosis. Br Med f 1976;ii:910-2.

7 Crandon AJ, Peel KR, Anderson JA, Thompson V, McNicol GP. Postoperative deep vein thrombosis: identifying high-risk patients. $\mathrm{Br} \mathrm{Med}$ f $1980 ; 281: 5278$.

${ }^{8}$ Blix S. Studies on the fibrinolytic system in the euglobulin fraction of human plasma. Scand $\mathcal{F}$ Clin Lab Invest 1961;13, suppl 58:3-19.
${ }^{9}$ Documenta Geigy. Scientific Tables. 7th ed. Macclesfield: Geigy Pharmaceuticals, 1970:712.

${ }^{10} \mathrm{Kakkar}$ W. The diagnosis of deep vein thrombosis using the ${ }^{125} \mathrm{I}$-fibrinogen test. Arch Surg 1972;104:152-9.

11 Ballard RM, Bradley-Watson PJ, Johnstone FD, et al. Low doses of subcutaneous heparin in the prevention of deep vein thrombosis after gynaecological surgery. Fournal of Obstetrics and Gynaecology of the British Commonwealth 1973;80:469-72.

12 Breckenridge RT, Ratnoff OD. Pulmonary embolism and unexpected death in supposedly normal persons. $N$ Engl f Med 1964 ;270:298-9.

${ }^{13}$ Havig O. Deep vein thrombosis and pulmonary embolism. Acta Chir Scand 1977;suppl 478.

${ }^{14}$ Pison J, Boyan P, Clifton EE. Fibrinolytic activity in patients during operation. FAMA 1965;191:1026-7.

15 Gordon-Smith IC, Hickman JA, Le Quesne LP. Postoperative fibrinolytic activity and deep vein thrombosis. Br $\mathcal{F}$ Surg 1974 ;61:213-8.

16 Knight MTN, Dawson R, Melrose DG. Fibrinolytic response to surgery: labile and stable patterns and their relevance to post-operative deep venous thrombosis. Lancet 1977;ii:370-3.

(Accepted 18 fune 1980)

\title{
Nephrotic syndrome with slight proliferative changes in the glomeruli: response to prednisone
}

\author{
H RASHID, S EZEDUM, A R MORLEY, D N S KERR
}

\section{Summary and conclusions}

Seven patients with slight but definite proliferative changes in the glomeruli achieved complete remission of the nephrotic syndrome when treated with prednisone. The patterns of response and, in three cases, repeated relapse and response suggested that this was more than a coincidental spontaneous cure.

A controlled trial of corticosteroids in patients with slight proliferative glomerulonephritis and severe nephrotic syndrome should be carried out to verify these results.

\section{Introduction}

The value of corticosteroids in the childhood nephrotic syndrome was established without the need for a controlled trial. Patients with minimal lesion (the great majority) responded rapidly, reproducibly, and almost without exception. ${ }^{1}$ The value of corticosteroids in adults was less certain, ${ }^{12}$ so in 1963 the MRC set up a multicentre, controlled trial of prednisone in adult nephrotic syndrome. ${ }^{3}$ This gave clear-cut results that have been accepted almost everywhere in Britain. Adults with minimal lesion responded to steroids, while those with membranous and proliferative change did not. Prednisone had a significant penalty in morbidity and mortality.

The trial made an important contribution in its time but had

\footnotetext{
Departments of Medicine and Pathology, University of Newcastle upon Tyne, Newcastle upon Tyne NE1 4LP

H RASHID, MB, FCPS, research fellow

S EZEDUM, MB, MRCP, research fellow (present address: Renal Unit, University of Nigeria Teaching Hospital, Enugu, Eastern Nigeria) A R MORLEY, MD, MRCPATH, consultant pathologist D N S KERR, MSC, FRCP, professor of medicine
}

certain limitations. These are particularly apparent to us, since $20 \%$ of the patients were cared for in Newcastle and this was the only centre where the planned repeat biopsies were consistently performed. The initial specimens were examined by only light microscopy, and in $18 \%$ of cases the panel of pathologists arrived at different diagnoses. Most of these "doubtful" cases, on the borderline between minimal lesion and membranous or proliferative nephritis, were eventually included in the "minimal" group. Retrospective analysis of our cases shows clearly that some early examples of membranous glomerulonephropathy were included in this group, and the report indicates that the same was probably true of slight proliferative lesions. This may account for the slow response to steroids in $25 \%$ of the patients in the "minimal" group. Since all the prednisonetreated patients in this group who survived to 24 months became "protein free," however, the possibility arises that some patients who are now diagnosed as having membranous or proliferative glomerulonephritis are denied the benefits of steroid treatment unnecessarily. We report here on seven patients who, we believe, fall into this group. All had slight but definite proliferative lesions yet went into complete remission while receiving corticosteroids.

\section{Methods}

Selection of cases-After the MRC study ended we stopped using corticosteroids for proliferative glomerulonephritis in general and conducted no further controlled trials. We continued, however, to give prednisone to a few carefully selected patients with incapacitating nephrotic syndrome whose biopsy changes were sufficiently slight that they might have fallen into the "doubtful" category in the MRC trial. We report here on seven of these patients, who went into complete remission while receiving steroids. None had any evidence of systemic diseases that respond to steroids (systemic lupus erythematosus, polyarteritis nodosa, Wegener's granulomatosis, etc) or of the forms of proliferative nephritis that often remit spontaneously or on treatment of the primary cause (acute post-streptococcal nephritis, nephritis of subacute bacterial endocarditis, shunt nephritis). 
Renal biopsy specimens were obtained percutaneously. All seven patients were examined by light microscopy, six by electron microscopy, and five by fluorescence microscopy for IgG, IgA, IgM, IgE, C3, and fibrinogen, using Hoechst fluorescein-labelled antisera in a direct reaction.

Patients-Table I summarises the clinical data on the patients (four male, three female), who were aged 14 to 41 . On admission all had nephrotic syndrome as defined by proteinuria of over $5 \mathrm{~g} / 24 \mathrm{~h}$, hypoalbuminaemia, and oedema. All had hypercholesterolaemia. None had macroscopic haematuria but three (cases 3,6, and 7) had microscopic haematuria. Differential protein clearance was studied in six patients by the technique of Cameron and Blandford 4 : three had selective and three poorly selective proteinuria. C3 concentration was normal in the six patients studied. Serum protein electrophoresis showed a classical nephrotic pattern in all. The initial titre of antistreptolysin was in the normal range in all patients, and serial readings in three patients failed to show any appreciable rise. A fluorescence test for antinuclear factor was negative in six patients. In case 4 one test was positive (titre of $1: 10$ ) before treatment but all seven subsequent tests were negative including five in the 30 months after the patient stopped all steroid treatment; she had no clinical features of systemic lupus erythematosus and DNA binding tests and serum C3 concentration were consistently normal.

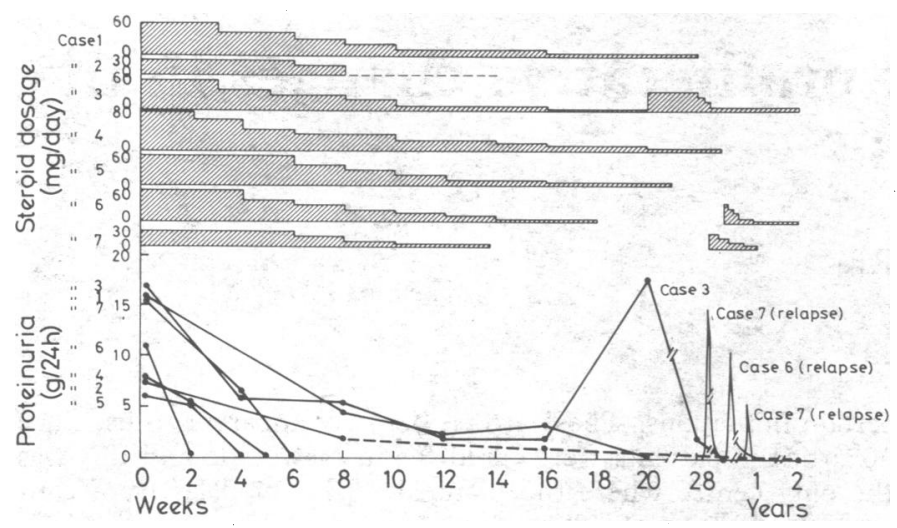

FIG 1-Effect of prednisone on proteinuria in all seven patients.

Renal histology-All seven patients had mild segmental or diffuse glomerular lesions in the form of hypercellularity or mesangial proliferation, or both (table II, figs 2-4). Immunofluorescence studies showed IgG deposits in case 3, IgG and C3 deposits in cases 1 and 7, fibrin deposits in case 4, and no deposits in case 6. Electron microscopy confirmed the segmental proliferation, but in no patient did we detect electron-dense deposits suggestive of immune complexes. No patient had any changes characteristic of systemic diseases such as polyarteritis or systemic lupus erythematosus.

Treatment-All patients received low-salt, high-protein diets and diuretics. Two patients (cases 6 and 7) received infusions of human serum albumin or purified plasma protein fraction to relieve severe oedema before prednisone was started. Prednisone was given in a dose of $30-80 \mathrm{mg}$ daily.

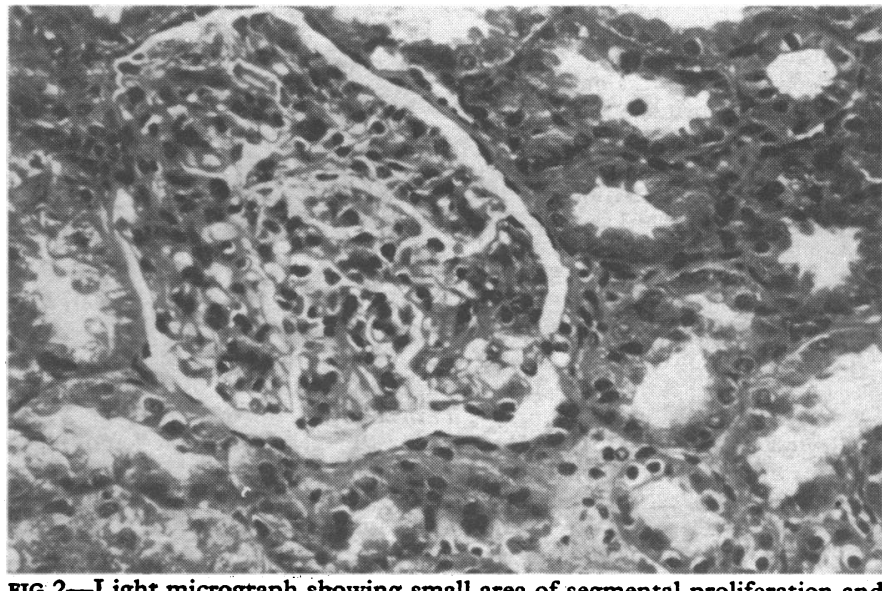

FIG 2-Light micrograph showing small area of segmental proliferation and foam cells (case 7). Basement membrane appears normal.



FIG 3-Electron micrograph showing widespread fusion of foot processe with appreciable microvillous transformation (case 1). No immune deposits. Basement membranes appear normal.

\section{Results}

Table I shows the initial proteinuria (mean $11.6 \mathrm{~g} / 24 \mathrm{~h}$ ). In case 1 the proteinuria fell from an average of $15.9 \mathrm{~g} / 24 \mathrm{~h}$ before steroids to $4.7 \mathrm{~g} / 24 \mathrm{~h}$ within eight weeks after starting prednisone; three months later the urine was protein free (fig 1). In case 2 protein excretion had fallen to $1.9 \mathrm{~g} / 24 \mathrm{~h}$ after eight weeks of prednisone. The patient was then discharged from hospital and followed up in a general medical clinic, where 24-hour collections were made at long and irregular intervals, so that we are uncertain of when she achieved a full

TABLE I-Clinical details of all seven patients

\begin{tabular}{|c|c|c|c|c|c|c|c|c|c|c|}
\hline Code No & Sex & $\begin{array}{c}\text { Age (years) } \\
\text { at } \\
\text { presentation }\end{array}$ & $\begin{array}{c}\text { Proteinuria } \\
\text { before } \\
\text { steroid } \\
\text { treatment }(\mathrm{g} / 24 \mathrm{~h})\end{array}$ & $\begin{array}{c}\text { Serum albumin } \\
\text { before } \\
\text { steroid } \\
\text { treatment }(g / 1)\end{array}$ & $\underset{(\mathbf{m g} / \mathbf{l})}{\mathrm{C} 3}$ & $\begin{array}{c}\text { Protein } \\
\text { selectivity }\end{array}$ & $\begin{array}{l}\text { Plasma protein } \\
\text { electrophoresis }\end{array}$ & $\begin{array}{l}\text { Microscopic } \\
\text { haematuria }\end{array}$ & $\begin{array}{c}\text { Initial } \\
\text { creatinine } \\
\text { clearance } \\
(1 / 24 \mathrm{~h})\end{array}$ & $\begin{array}{c}\text { Duration of } \\
\text { remission } \\
\text { (months) }\end{array}$ \\
\hline 1 & $\mathbf{M}$ & 16 & $15 \cdot 9$ & 12 & 1.32 & $\begin{array}{c}0.28 \\
\text { Poorly }\end{array}$ & $\mathrm{Alb} \downarrow \alpha_{3} \uparrow \gamma \uparrow$ & None & 113.0 & 41 \\
\hline 2 & $\mathbf{F}$ & 33. & $7 \cdot 4$ & 10 & & & Alb $\downarrow \alpha_{2} \uparrow$ & None & $67 \cdot 5$ & 88 \\
\hline 3 & $\mathbf{M}$ & 15 & 16.9 & 11 & 1.02 & $\begin{array}{c}0.21 \\
\text { Poorly }\end{array}$ & Alb $\downarrow \alpha_{2} \uparrow \gamma \downarrow$ & Present & $69 \cdot 1$ & 48 \\
\hline 4 & $\mathbf{F}$ & 41 & $8 \cdot 35$ & 12 & 0.80 & 0.05 & Alb $\downarrow \alpha_{2} \uparrow \gamma \downarrow$ & None & $120 \cdot 0$ & 48 \\
\hline 5 & $\mathbf{F}$ & 22 & 6.0 & 14 & 1.32 & $\begin{array}{l}\text { Selective } \\
0.17\end{array}$ & Alb $\downarrow \alpha_{2} \uparrow \gamma \downarrow$ & None & $100 \cdot 0$ & 44 \\
\hline 6 & $\mathbf{M}$ & 14 & $11 \cdot 0$ & 12 & 1.22 & $\begin{array}{l}\text { Selective } \\
0 \cdot 27 \\
\text { Poorly }\end{array}$ & Alb $\downarrow \alpha_{2} \uparrow \gamma \downarrow$ & Present & $93 \cdot 0$ & 41 \\
\hline 7 & $\mathbf{M}$ & 15 & $15 \cdot 8$ & 9 & $1 \cdot 24$ & $\begin{array}{c}0 \cdot 11 \\
\text { Selective }\end{array}$ & Alb $\downarrow \alpha_{2} \uparrow \gamma \downarrow$ & Present & $57 \cdot 6$ & 60 \\
\hline
\end{tabular}


TABLE II-Results of light, immunofluorescence, and electron microscopy

\begin{tabular}{|c|c|c|c|}
\hline Case No & Light microscopy & Immunofluorescence study & Glomerular electron microscopy \\
\hline 1 & $\begin{array}{l}\text { Focal and segmental hypercellularity and } \\
\text { mesangial increase. Capsular adhesion in some } \\
\text { glomeruli. Normal basement membrane }\end{array}$ & $\begin{array}{l}\text { Segmental distribution of IgM. Tubular droplet } \\
\text { contained IgG, IgM, IgA, and complement }\end{array}$ & $\begin{array}{l}\text { Foot process fusion present. No electron-dense } \\
\text { deposits (see fig 3) }\end{array}$ \\
\hline 2 & $\begin{array}{l}\text { Mild segmental proliferation of glomerular tuft } \\
\text { Focal and segmental hypercellularity and } \\
\text { mesangial increase, with capsular adhesions. } \\
\text { Occasional glomerular foam cells }\end{array}$ & $\begin{array}{l}\text { Not done } \\
\text { Glomeruli showed focal distribution of IgA } \\
\text { (Gr I), fibrin, and IgG }\end{array}$ & $\begin{array}{l}\text { Not done } \\
\text { Widespread foot process fusion, patchy } \\
\text { subendothelial thickening. Mild increase in } \\
\text { mesangial matrix. No electron-dense deposits }\end{array}$ \\
\hline 4 & $\begin{array}{l}\text { Mild mesangial proliferation. Normal basement } \\
\text { membrane }\end{array}$ & $\begin{array}{l}\text { Glomeruli showed finely granular and linear } \\
\text { deposition of fibrin (grade } 2-3)^{*}\end{array}$ & $\begin{array}{l}\text { Widespread foot process fusion, slight wrinkling } \\
\text { of basement membrane. Increased mesangial }\end{array}$ \\
\hline 5 & Mild mesangial increase & Not done & $\begin{array}{l}\text { matrix. No electron-dense deposits } \\
\text { Widespread foot process fusion. Normal } \\
\text { basements and no evidence of electron-dense } \\
\text { deposits in capillary loops and mesangium }\end{array}$ \\
\hline 6 & $\begin{array}{l}\text { Mild lobularity and increase in mesangial } \\
\text { cellularity, capsular adhesion in some } \\
\text { glomeruli. Basement membrane normal }\end{array}$ & $\begin{array}{l}\text { No significant deposition of } \mathrm{IgG}, \mathrm{IgM}, \mathrm{C} 3 \text {, or } \\
\text { fibrin }\end{array}$ & $\begin{array}{l}\text { deposits in capillary loops and mesangium } \\
\text { Widespread foot process fusion, with } \\
\text { microvillous podocyte change, mesangial cell } \\
\text { and matrix increase. Cytoplasm filling some } \\
\text { capillary loop. No electron-dense deposits } \\
\text { (see fig 4) }\end{array}$ \\
\hline 7 & $\begin{array}{l}\text { Mild mesangial increase. Small areas of segmental } \\
\text { sclerosis (see fig 2) and foam cells. Basement } \\
\text { membrane appeared normal }\end{array}$ & $\begin{array}{l}\text { All glomeruli showed diffuse granular deposition } \\
\text { of complement (grade 2-3) and mild segmental } \\
\text { IgM (grade } 0 \cdot 5-1 \cdot 0 \text { ) }\end{array}$ & $\begin{array}{l}\text { Widespread foot process fusion. Membranes } \\
\text { showed subendothelial thickening. No } \\
\text { electron-dense deposits }\end{array}$ \\
\hline
\end{tabular}

*Subjective immunofluorescence scale $0,0.5,1,2,3,4$.

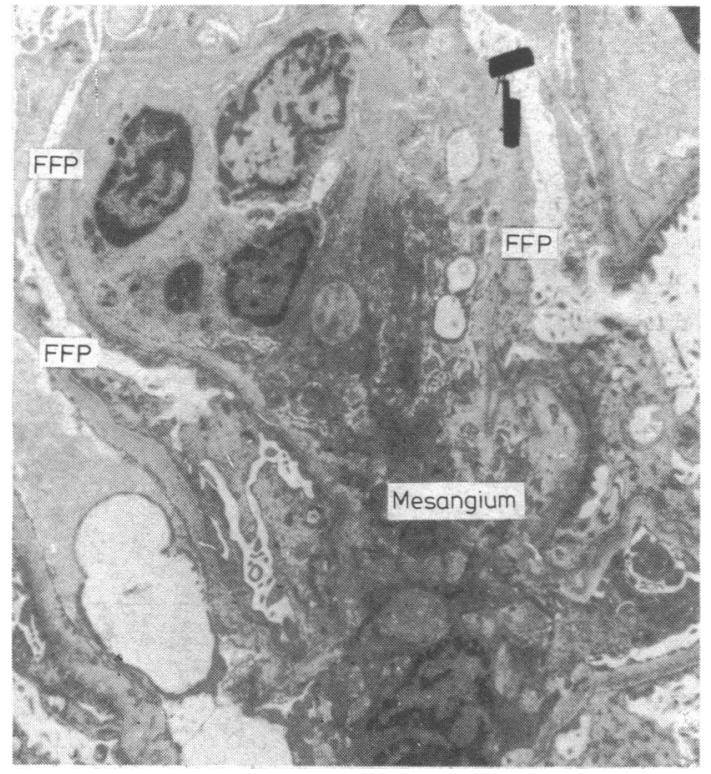

FIG 4-Electron micrograph showing widespread fusion of foot processes (FFP) with microvillous podocyte change and mesangial cell and matrix increase (case 6). No electrondense deposit.

remission. Her urine was consistently free of protein two years after starting prednisone. In case 3 protein excretion averaged $16.9 \mathrm{~g} / 24 \mathrm{~h}$ before treatment and $5.9 \mathrm{~g} / 24 \mathrm{~h}$ after four weeks of prednisone. It remained at this level as the prednisone dose was reduced to $5 \mathrm{mg}$ daily, when the patient relapsed with proteinuria of $18 \mathrm{~g} / 24 \mathrm{~h}$. Prednisone was increased to $40 \mathrm{mg}$ daily, and the proteinuria dropped to $2 \mathrm{~g} / 24 \mathrm{~h}$ within eight weeks. Proteinuria continued to decline and had disappeared after a further four months. He continued to take a maintenance dose of prednisone $5 \mathrm{mg} /$ day, in full remission. The four remaining patients (cases 4-7) all lost their proteinuria rapidly after starting prednisone; they were excreting no detectable protein within five, four, two, and six weeks respectively.

The patients showed other evidence of response to steroids over eight to 16 weeks. The changes in serum protein concentrations were those that would be expected with a declining proteinuria-that is, significant rises in serum albumin $(p<0.01)$ and total protein $(p<0.01)$ concentrations. Serum cholesterol concentration fell from a mean of 16.7 to $6.2 \mathrm{mmol} / 1$ (646 to $240 \mathrm{mg} / 100 \mathrm{ml}-\mathrm{p}<0.01)$. Serum immunoglobulins were determined in four patients: mean IgG concentration rose from 4.1 to $7.9 \mathrm{~g} / 1(\mathrm{p}<0.02)$ and IgM fell from 2.26 to $1.73 \mathrm{~g} / 1$ (not significant), but there was variable, non-significant change in serum IgA concentrations.

All patients were followed up for 41-88 months after stopping the prednisone. One patient (case 6) relapsed after six months but remained in full remission taking $2.5 \mathrm{mg}$ prednisone on alternate days. Another patient (case 7) suffered two relapses, eight months and five months respectively after treatment was stopped; in each instance resuming the treatment resulted in complete and sustained remission.

\section{Discussion}

The results of the MRC trial of steroids in the nephrotic syndrome ${ }^{3}$ were accepted almost everywhere in Britain; in other parts of the world, where controlled trials are held in lower esteem, many clinicians continued to try steroids in the nephrotic syndrome, regardless of the histology. The confusing reports they produced were well reviewed by Cameron. ${ }^{5}$ In the uncontrolled trials "remission" has no universal meaning-it may refer to reduction in oedema or proteinuria rather than complete restoration of normality-and is often difficult to distinguish from spontaneous change in the course of the illness. We defined remission as complete disappearance of proteinuria on quantitative tests (salicylosulphonic acid or biuret test, or both) and qualitative tests (Labstix or Albustix, or both) and complete restoration of the urinary deposit to normal on repeated examinations.

We cannot exclude the possibility that three of our patients underwent spontaneous remission; but we think that this is unlikely in the remaining four, since (a) the proteinuria disappeared rapidly after steroid treatment was started, in a pattern similar to that seen in minimal change, and $(b)$ three of the patients relapsed when steroids were reduced or withdrawn and responded a second (in one case a third) time when they were started again.

Minimal-change and slight proliferative glomerulonephritis are hard to distinguish on light microscopy. Several authors have reported a slight hypercellularity of the glomeruli in minimal change, ${ }^{6-8}$ typically an increase of about $25 \%$ in the number of cells seen in a cross-section of the glomerulus compared with normal ${ }^{9}$; and although selective proteinuria is typical of minimal change, a few patients with unselected proteinuria are found in most strictly reported series. ${ }^{1011} \mathrm{We}$, however, classified our patients as having proliferative glomerulonephritis, since they all showed one or more features that are not typical of minimal change-namely, segmental proliferation, tuft adhesions, mesangial hyperplasia and positive fluorescence for immunoglobulins or complement factors, nonselective proteinuria, and microscopic haematuria. Some histologists would accept patients with one or more of these features within their definition of minimal change, but we suspect that most patients with these features are now classified as having proliferative glomerulonephritis and may, therefore, be denied a trial of corticosteroid treatment. 
Complete remission of the nephrotic syndrome, as we have defined it, is uncommon when glomerulonephritis is treated with corticosteroids. Over 50 patients in Newcastle received corticosteroids for proliferative glomerulonephritis during the past 15 years, including those in the MRC trials of steroids alone and steroids plus azathioprine, and these are the only seven patients who responded as we describe. They are distinguished from most patients with this disease (or diseases) by the absence of features with a poor prognosis such as crescent formation, tubular atrophy, and interstitial scarring, by the limited extent and severity of the proliferation, and by the absence of electron-dense deposits on electron microscopy. They are predominantly young, four of the seven being teenagers.

Not all patients who fit this description respond to corticosteroids, and we have no way of distinguishing those who will from those who will not. We therefore suggest the need for a further controlled trial of corticosteroids in the nephrotic syndrome associated with slight proliferative changes in the glomeruli. Such a trial would have to be multicentred, since such patients are fairly uncommon. The availability of light, electron, and fluorescence microscopy in most renal centres and the participation of most of these centres in the MRC working party on glomerulonephritis should make such an enterprise eminently feasible.

Pending such a controlled study, we think it reasonable to offer a trial of corticosteroid treatment to patients with troublesome nephrotic syndrome associated with slight proliferative lesions. The doses required to initiate and maintain a remission in our patients are usually well tolerated by young adults, and none of our patients suffered any serious ill effects from their treatment; this type of proliferative glomerulonephritis is rare in older patients, who would be more likely to suffer side effects from corticosteroid treatment. Our experience suggests that a trial of treatment should last for at least two months, but if any patient has not responded by four months he is unlikely to respond thereafter.

Requests for reprints should be addressed to: Professor D N S Kerr, Department of Medicine, Royal Victoria Infirmary, Newcastle upon Tyne NE1 4LP.

\section{References}

1 Cameron JS. The natural history of glomerulonephritis. In: Black DAK, ed. Renal disease. 3rd edn. Oxford: Blackwell, 1972:304-7.

${ }^{2}$ Robson JS. The nephrotic syndrome. In: Black DAK, ed. Renal disease 3rd edn. Oxford: Blackwell, 1972:357-8.

3 Black DAK, Rose G, Brewer DB. Controlled trial of prednisone in adult patients with the nephrotic syndrome. $B r$ Med $f 1970$;iii:421-6.

4 Cameron JS, Blandford G. The simple assessment of selectivity in heav proteinuria. Lancet 1966 ;ii:242-7.

${ }^{5}$ Cameron JS. Immunosuppressant agents in the treatment of glomerulonephritis. F $R$ Coll Physicians Lond 1971 ;5:282-322.

${ }^{6}$ Churg J, Habib R, White RHR. Pathology of the nephrotic syndrome in children. A report for the International Study of Kidney Disease in Children. Lancet 1970;i:1299-302.

${ }^{7}$ Hopper J, Ryan P, Lee JC, Rosenau W. Lipoid nephrosis in 31 adul patients: renal biopsy study by light, electron and fluorescence microscopy with experience in treatment. Medicine 1970;49:321-41.

${ }^{8}$ Grishman E, Churg J. Pathology of nephrotic syndrome with minimal or minor glomerular changes. In: Kincaid-Smith $P$, Mathew $T H$, Becker EL, eds. Glomerulonephritis: morphology, natural history, and treatment. New York: Wiley, 1973:165-81.

${ }^{9}$ Sharon Z, Schwartz MM, Pauli BU, Lewis EJ. Glomerular cellularity in lipoid nephrosis Kidney Int 1976;10:550.

${ }^{10}$ Cameron JS, Turner DR, Ogg CS, Sharpstone P, Brown CB. The nephrotic syndrome in adults with "minimal change" glomerular lesions. $Q \mathcal{F}$ Med $1974 ; 43: 461-88$.

11 Cameron JS. Histology, protein clearances, and response to treatment in the nephrotic syndrome. $\mathrm{Br}$ Med $\mathcal{F} 1968$;iv:352-6.

(Accepted 3 fune 1980)
ONE HUNDRED YEARS AGO In a paper read before the auxiliary department of Medicine in the University of Pennsylvania, and published in the Philadelphia Medical Times for May 8th, Dr J M Anders discusses the question of the effect produced on the health of those who inhabit rooms in which plants are kept. It has generally hitherto been a popular belief that plants in a room are injurious, especially in the sleeping-room and sick-room. Dr Anders has, however, arrived at a very different conclusion from his investigations. He regards the three functions of plant-life-the absorption of carbonic acid, the exhalation of oxygen, and the generation of ozone-as of inferior importance (for the present purpose) in comparison with transpiration, or the exhalation of moisture by the leaves; and he believes that we possess in plants a valuable means of increasing the humidity in rooms warmed by dry air. "In all instances in which artificial heat is used, but particularly in the case of dry air, as that furnished by furnaces, plants become, under proper regulations, hygienic agents of special value." Dr Anders further says; "Of course, it is chiefly in diseases of a chronic nature, and particularly those affecting the lungs and air-passages, that we should expect to derive good results from such a measure as stocking the sick-room with growing plants, for it is in such cases that dry heat does the most harm. Still, they would prove beneficial also, in a less degree, in acute diseases, especially the continued fevers, and perhaps membraonus croup, where moisture in the air is so desirable. House-plants have, however, a sphere of usefulness which is independent of atmospheric humidity. In nervous disorders of the functional class, such as melancholia and chlorosis, in diseases of the mind proper, and other allied conditions (excessive grief, ennui, etc), where it is necessary to divert the mind or relieve tension, nothing is more efficient than the pleasing occupation of studying and caring for plants." It is, however, in phthisis that Dr Anders expects the greatest success from plants as therapeutic agents. In order to obtain information bearing on the point, he asked his brother practitioners for a statement of their observations on the effect of plants on the sick. Almost universally, the reply was that their attention had never been directed to the subject. Dr Hiram Corson, however, informed him that three of his brothers and a sister died of consumption, the disease having been inherited from the mother, who herself, her sisters, and brother, with other members of the family, all fell victims to the malady, which however, in several instances did not appear until they were advanced in age. One of Dr Corson's sisters was reported, when fifty years of age, to be in a hopeless state of tubercular consumption. She was, however, ardently fond of plants and flowers, and cultivated them both in her garden and in her room, to which she was confined during the winter. She lived-notwithstanding that threatening phthisical symptoms occurred every winter-to the age of eight-five. To obtain further information, $\mathrm{Dr}$ Anders questioned the gardeners and florists of Philadelphia. The general result was, that he found them to be in good health, except in cases where rheumatism or cold could be traced to exposure to cold and wet; and that, in some cases, the pursuit of gardening appeared to arrest consumption in persons of phthisical tendency, while the abandonment of the pursuit in other cases led to the development of the disease. He does not believe that the keeping of plants will cure confirmed phthisis, but that it may prolong life and ameliorate the distressing symptoms. In selecting plants for cultivation in rooms, the chief points to be borne in min are these. 1. They should have soft thin leaves. 2. Plants having extensive leaf-surface are to be preferred. 3 . Those which are highly scented should be avoided, as they often give rise to headache and other unpleasant symptoms. Dr Anders recommends a room well stocked with plants as a complete and agreeable "health-resort," free from the inconveniences of travelling and the anxiety of separation from home. He has opened up a most interesting subject for investigation. (British Medical f́fournal, 1880.) 